\title{
Morphological and Physiological Responses of Cucumber Seedlings to Supplemental LED Light under Extremely Low Irradiance
}

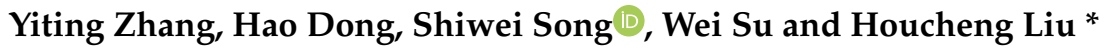 \\ College of Horticulture, South China Agricultural University, Guangzhou 510642, China; \\ yitingzhang@scau.edu.cn (Y.Z.); donghao@scau.edu.cn (H.D.); swsong@scau.edu.cn (S.S.); \\ susan_l@scau.edu.cn (W.S.) \\ * Correspondence: liuhch@scau.edu.cn; Tel.: +020-8528-0464
}

Received: 25 September 2020; Accepted: 30 October 2020; Published: 2 November 2020

\begin{abstract}
In order to inhibit spindling growth and improve quality of cucumber seedlings under low irradiance, effects of supplemental light-emitting diodes (LED) light (SL) on morphological and physiological characteristics of cucumber seedlings at different growth stages under extremely low irradiance (ELI) were investigated. Supplementary monochromatic, dichromatic and trichromatic LED light on cucumber seedlings were conducted in experiment one, and supplements of combination ratios and intensity of blue and red LED light (RB) were conducted in experiment two. The morphological and physiological parameters of cucumber seedlings were promoted effectively by supplemental monochromatic red light or dichromatic containing red light (RB and RG) under ELI as early as one-leaf seedling stage, as demonstrated by suppressed length of hypocotyl and first internode, increased stem diameter and biomass, higher net photosynthetic rate $\left(\mathrm{P}_{\mathrm{n}}\right)$ and soluble sugar content. Monochromatic or additional green light was not beneficial to cucumber seedlings under the ELI. The length of shoot and hypocotyl decreased, while stem diameter and leaf area increased as early as one-leaf seedling stage by RB SL. Root activities, root-shoot ratio, activities of catalase (CAT) and peroxidase (POD), as well as palisade-spongy ratio in the leaf of cucumber seedlings were promoted effectively by increasing blue light proportion (1R1B/1R2B). Increasing light intensity (50/75) enhanced soluble sugar accumulation in leaves. There were synergistic effects of RB ratio and light intensity on increasing stem diameter, leaf area, seedling index and decreasing hypocotyl cell area of the vertical section. In conclusion, 1R2B-75 may be the optimal SL to inhibit spindling growth of cucumber seedlings under ELI condition.
\end{abstract}

Keywords: extremely low irradiance; supplemental light; hypocotyl; cucumber seedling; combination of red and blue LED

\section{Introduction}

As one of the primary greenhouse vegetables, cucumber is widely cultivated in China. However, spindling (elongated hypocotyl, lower dry weight and seedling index, etc.) often appeared in cucumber seedling production in protected horticulture, when they suffered from continuous rainy or cloudy weathers, especially during winter or early-spring growing seasons. This disorder is a major limitation to the success of commercial production, as well as transplant quality and subsequent formation of yield and quality. Supplementary artificial lighting was considered as the most effective way to inhibit spindling growth and produce high-quality seedlings [1], which has been commonly used in areas, and during seasons, with low irradiance intensity [2-5].

Light-emitting diodes (LED) represent a promising light source for protected horticulture, which can be used as supplemental light (SL) or a main light source. Blue light is involved in a wide range of plant 
processes such as phototropism, photomorphogenesis, stomatal conductance, and leaf photosynthetic functioning [6], which causes stomatal opening through phototropin mediated activation of $\mathrm{H}^{+}$-ATPases in stomatal guard cells [7]. Red LED light has the highest relative quantum yield from the Photosynthetically Active Radiation (PAR) spectrum [8], and chlorophyll absorption peaks are also closer to the red spectrum [9]. Green light has been reported to reverse some blue light responses, such as inhibition of hypocotyl elongation and stomatal conductance in seedlings [10].

The combination of red and blue light has significantly synergistic effects on stomatal density in cucumber seedlings [11]. Blue light was more effective than red light in enhancing photosynthetic electron transport and the activities of photosystem II and I and in cucumber leaves [12]. Increasing percentage of blue light could promote hydraulic conductance, net photosynthetic rate $\left(P_{n}\right)$, stomatal conductance $\left(G_{S}\right)$, and chlorophyll concentration in cucumber seedlings [11,13] and tomato seedlings [14]. Morphological and growth parameters of cucumber [15] and tomato seedlings [5] were all improved by the combination of blue and red light, but there were no significant differences among different B:R ratios. In contrast, Nanya et al. [16] found that the net photosynthesis rate increased with the decrease in blue light percent and increase in red light percent in tomato.

Our previous studies found that the growth of cucumber seedlings was significantly improved by supplemental red or blue LED light, indicated by high seedling index and dry weight [17]. Moreover, supplemental blue and red light significantly suppressed hypocotyl elongation through interaction of light signals, GA/BR and CSPIF4, in cucumber seedlings. Red and blue light might directly affect photomorphogenesis of cucumber seedlings through mediating CsPHYA/B and CsCRY1/2, respectively [18].

There are many pieces of research concerning the effects of SL on cucumber growth and development in normal or low irradiance conditions; however, little research was available on SL regulating spindling growth in extremely low irradiance (ELI) conditions in greenhouses, which is very essential because spindling growth often appeared under ELI conditions. SL was provided in photosynthetic daily light integral as low as $5.2 \pm 1.2 \mathrm{~mol} \cdot \mathrm{m}^{-2} \cdot \mathrm{d}^{-1}$ as compared with a high one at $16.2 \pm 5.3 \mathrm{~mol} \cdot \mathrm{m}^{-2} \cdot \mathrm{d}^{-1}$ [5]. However, seedlings sometimes suffered from ELI $<$ Photosynthetic Photon Flux Density (PPFD) $100 \mu \mathrm{mol} \cdot \mathrm{m}^{-2} \cdot \mathrm{s}^{-1}$.

In this study, we aimed to widen the understanding of SL effects on morphological and physiological characters of cucumber seedlings and to provide information for inhibiting spindling growth and promoting photosynthesis of seedlings under ELI. Therefore, under an ELI condition $\left(35 \mu \mathrm{mol} \cdot \mathrm{m}^{-2} \cdot \mathrm{s}^{-1}\right)$, by using shade screen, cucumber seedlings were treated with supplementary monochromatic, dichromatic and trichromatic LED light in experiment one, and a different combination ratio and intensity of blue and red LED light in experiment two, and the effects of SL on seedling growth, photosynthesis and antioxidant enzyme activity were investigated.

\section{Materials and Methods}

\subsection{Plant Materials and Cultural Conditions}

Cucumber (Cucumis sativus L. cv. Yuexiu no. 3) seeds were sown into 72-cell plug trays $(2.7 \mathrm{~cm}$ $\times 2.7 \mathrm{~cm} ; 12 \mathrm{~mL}$ volume), which were filled with mixed substrate of peat:coconut coir:perlite = 1:1:1 (v:v:v). LED tubes produced by Kedao Co. (Huizhou, China; green light: 520-540nm, blue light: 450-460 nm, red light: $630-660 \mathrm{~nm}$ ) were applied as a SL source. Seedlings with fully expended cotyledons were irrigated with Yamazaki $\left(\mathrm{Ca}\left(\mathrm{NO}_{3}\right)_{2} \cdot 4 \mathrm{H}_{2} \mathrm{O} 826 \mathrm{mg} / \mathrm{L}, \mathrm{KNO}_{3} 607 \mathrm{mg} / \mathrm{L}, \mathrm{NH}_{4} \mathrm{H}_{2} \mathrm{PO}_{4}\right.$ $153 \mathrm{mg} / \mathrm{L}, \mathrm{MgSO}_{4} \cdot 7 \mathrm{H}_{2} \mathrm{O} 370 \mathrm{mg} / \mathrm{L}, \mathrm{NaFe}-\mathrm{EDTA} 20 \mathrm{mg} / \mathrm{L}, \mathrm{H}_{3} \mathrm{BO}_{3} 2.86 \mathrm{mg} / \mathrm{L}, \mathrm{MnSO}_{4} \cdot 4 \mathrm{H}_{2} \mathrm{O} 2.13 \mathrm{mg} / \mathrm{L}$, $\left.\mathrm{ZnSO}_{4} \cdot 7 \mathrm{H}_{2} \mathrm{O} 0.22 \mathrm{mg} / \mathrm{L}, \mathrm{CuSO}_{4} \cdot 5 \mathrm{H}_{2} \mathrm{O} 0.08 \mathrm{mg} / \mathrm{L},\left(\mathrm{NH}_{4}\right)_{6} \mathrm{Mo}_{7} \mathrm{O}_{24} \cdot 4 \mathrm{H}_{2} \mathrm{O} 0.02 \mathrm{mg} / \mathrm{L}\right)$ nutrient solution once a day. Both experiments were performed in a greenhouse in the College of Horticulture, South China Agriculture University. The cultivation system and management for the greenhouse were the same as in our previous research [18]. The average day/night temperature was $25-28^{\circ} \mathrm{C} / 16-20^{\circ} \mathrm{C}$, 
relatively humidity was $60 \%-70 \%$ and $\mathrm{CO}_{2}$ was ambient. After germination, different SL treatments were established.

\subsection{Light Treatments}

Shading screens were used to create ELI conditions, the SL experiments were conducted under ELI from 06:00 to 18:00 every day. In experiment one, cucumber seedlings were placed under the following constant $25 \pm 5 \mu \mathrm{mol} \cdot \mathrm{m}^{-2} \cdot \mathrm{s}^{-1}$ PPFD SL light conditions: (1) CK, no SL, 0-35 $\mu \mathrm{mol} \cdot \mathrm{m}^{-2} \cdot \mathrm{s}^{-1}$ PPFD, (2) G, monochromatic green light, (3) B, monochromatic blue light, (4) R, monochromatic red light, (5) RB, red:blue $=1: 1,(6) \mathrm{RG}$, red:green $=1: 1,(7) \mathrm{GB}$, green:blue $=1: 1,(8) \mathrm{RGB}$, red:green:blue $=1: 1: 1$.

In experiment two, there were 4 SL treatments: CK (no SL, 0-35 $\mathrm{mol} \cdot \mathrm{m}^{-2} \cdot \mathrm{s}^{-1} \mathrm{PPFD}$ ), $1 \mathrm{R} 1 \mathrm{~B}-50$ $\left(\mathrm{R}: \mathrm{B}=1: 1,50 \pm 5 \mu \mathrm{mol} \cdot \mathrm{m}^{-2} \cdot \mathrm{s}^{-1} \mathrm{PPFD}\right), 1 \mathrm{R} 2 \mathrm{~B}-50\left(\mathrm{R}: \mathrm{B}=1: 2,50 \pm 5 \mu \mathrm{mol} \cdot \mathrm{m}^{-2} \cdot \mathrm{s}^{-1} \mathrm{PPFD}\right), 1 \mathrm{R} 1 \mathrm{~B}-75$ $\left(\mathrm{R}: \mathrm{B}=1: 1,75 \pm 5 \mu \mathrm{mol} \cdot \mathrm{m}^{-2} \cdot \mathrm{s}^{-1} \mathrm{PPFD}\right), 1 \mathrm{R} 2 \mathrm{~B}-75\left(\mathrm{R}: \mathrm{B}=1: 2,75 \pm \mu \mathrm{mol} \cdot \mathrm{m}^{-2} \cdot \mathrm{s}^{-1} \mathrm{PPFD}\right)$.

A total of 2808 seedlings were cultivated in both experiments. Three replicates for each treatment were adopted, and each replicate contained one seedling tray with 72 cells. Then, 36 seedlings in each replicate (72 cell tray) were randomly selected and separated into 3 parts for investigation: 24 for morphology, growth, and photosynthetic characteristics, 24 for physiological and antioxidant enzyme activity investigation, and 12 for microstructure and ultrastructure observation.

\subsection{Measurement and Statistical Analyses}

\subsubsection{Morphology and Growth Characteristics}

When cucumber seedlings had three fully expanded true leaves, morphology and growth characteristics were investigated. Shoot length from the basal part to apical point, hypocotyl length from the basal part to cotyledonary node and the first internode length between the cotyledonary node and the first true leaf were measured by a ruler. Stem diameter at $1 \mathrm{~cm}$ below the cotyledonary node was measured by a digital caliper. Leaf area per plant was measured by a leaf area meter (Li-3000A, LI-COR Inc., Lincoln, NE, USA). Number of leaves that had a width greater than $2 \mathrm{~cm}$ per plant were counted. The fresh weight of shoots was recorded using an electronic balance, whereas the dry weight was recorded after seedlings were heated to de-enzyme at $105^{\circ} \mathrm{C}$, then dried at $80{ }^{\circ} \mathrm{C}$ till constant. Seedling index $=($ stem diameter/shoot length $) \times$ plant dry weight .

\subsubsection{Physiological Characteristics}

Root activity was analyzed by the triphenyltetrazolium chloride (TTC) method [19] and expressed as the deoxidization ability. Then, $0.5 \mathrm{~g}$ of fresh root was immersed in $10 \mathrm{~mL}$ of equally mixed solution of $0.4 \%$ TTC and phosphate buffer ( $\mathrm{pH} 7.0$ ) and kept in the dark at $37^{\circ} \mathrm{C}$ for $2 \mathrm{~h}$. Then, $2 \mathrm{~mL}$ of $1 \mathrm{~mol} \cdot \mathrm{L}^{-1} \mathrm{H}_{2} \mathrm{SO}_{4}$ was added to stop the reaction with the root. The root was dried with filter paper and then extracted with ethyl acetate. The extract was measured at $485 \mathrm{~nm}$ by a UV-spectrophotometer.

Chlorophyll content was analyzed according to Porra et al. [20]. The sample (1 g) was homogenized by $20 \mathrm{~mL}$ of $80 \%(v / v)$ acetone. The absorbance at 663 (OD 663) and $645 \mathrm{~nm}$ (OD 645) was determined by a UV-spectrophotometer (Shimadzu UV-16A, Shimadzu, Corporation, Kyoto, Japan). Total chlorophyll $\left(\mathrm{mg} \cdot \mathrm{L}^{-1}\right)=8.02 \times \mathrm{OD} 663+20.20 \times$ OD 645 .

The soluble proteins content was measured by the Coomassie brilliant blue method [21]. Then, $0.5 \mathrm{~g}$ of fresh sample was homogenized in a mortar with liquid nitrogen, to which $5 \mathrm{~mL}$ of phosphate-buffered solution ( $\mathrm{pH} 7.0$ ) was added. The extract was centrifuged at $10,000 \times \mathrm{g}$ for $10 \mathrm{~min}$ at $4{ }^{\circ} \mathrm{C}$, and $0.3 \mathrm{~mL}$ of the supernatant was combined with $0.7 \mathrm{~mL}$ of distilled water and $5 \mathrm{~mL}$ of Coomassie brilliant blue G-250 solution $(0.1 \mathrm{~g} / \mathrm{L})$. After $2 \mathrm{~min}$, the absorbance at $595 \mathrm{~nm}$ was determined by a UV-spectrophotometer.

The soluble sugars content was measured by the method of sulfuric acid anthrone (Sigma, Louis, MO, USA) [22]. Then, $0.5 \mathrm{~g}$ of fresh leaves were put into a test tube, $10 \mathrm{~mL}$ of distilled water was added and mixed. After $30 \mathrm{~min}$ in a water bath at $85^{\circ} \mathrm{C}$, the supernatant was collected, and this step was repeated twice. Next, $0.1 \mathrm{~mL}$ of sample extract was added to a test tube with a volume of $20 \mathrm{~mL}$, 
and $1.9 \mathrm{~mL}$ of distilled water was added, then $0.5 \mathrm{~mL}$ of ethyl anthrone acetate reagent and $5 \mathrm{~mL}$ of concentrated sulfuric acid were added to the test tube, with vigorous shaking. After cooling to ambient temperature, the soluble sugar content was determined at $630 \mathrm{~nm}$ with a UV-spectrophotometer.

\subsubsection{Photosynthetic Characteristics}

The net photosynthetic rates $\left(P_{n}\right)$, stomatal conductance $\left(G_{s}\right)$, intercellular $C_{2}$ concentration $\left(C_{i}\right)$ and transpiration rate (Ts) of the second true leaf were measured by a TPS-2 portable photosynthetic system (PP System, Amesbury, MA, USA) during 9:00 to 11:00 on sunny days. A total of 10 fully expanded leaves from the five seedlings of each group were randomly selected for measurements under ambient light and $\mathrm{CO}_{2}$ concentration.

\subsubsection{Antioxidant Enzyme Activity}

For antioxidant enzyme extraction, $0.5 \mathrm{~g}$ of fresh leaf was ground in $5 \mathrm{~mL} 50 \mathrm{mM}$ sodium phosphate buffer ( $\mathrm{pH} 7.0$ ) (ice cold), the homogenates were centrifuged at 10,000 rpm for $20 \mathrm{~min}$ at $4{ }^{\circ} \mathrm{C}$, and the supernatant was used for the determination of enzyme activity, the activity of sodium dismutase (SOD) was estimated according to Giannopolitis and Ries [23], peroxidase (POD) activity was estimated according to Kochba et al. [24], and catalase (CAT) was according to Cakmak and Marschner [25], respectively.

\subsubsection{Microstructure and Ultrastructure Observation}

Microstructural characteristics of hypocotyl cells and mesophyll cells were observed by performing standard paraffin sectioning as described by Naijia et al. [26]. The hypocotyl at $1 \mathrm{~cm}$ below the cotyledon node and selected leaf samples were fixed in formaldehyde/ethanol/acetic acid (FAA) 10:85:5 (v/v/v), dehydrated in alcohol series between $70 \%$ and 100\%, transferred into gradual alcohol-xylol series and finally embedded in paraffin. Samples were cut with a rotatory microtome (Leica, RM2125 RT, Solms, Germany) and observed under microscope (OLYMPUS DP12, Shinjuku, Tokyo, Japan). The ultrastructure of hypocotyl cells was observed by transmission electron microscopy (FEI Tecnai 12, Hillaborough, OR, USA), the hypocotyl samples at $1 \mathrm{~cm}$ below cotyledon node were fixed with $3.5 \%$ glutaraldehyde for $24 \mathrm{~h}$ and were washed with a $0.1 \mathrm{M}$ phosphate buffer ( $\mathrm{pH}$ 7.0). The samples were then post-fixed with $1 \%$ osmic acid at $4{ }^{\circ} \mathrm{C}$ for $4 \mathrm{~h}$, dehydrated with ethanol and embedded in Spurr resin at $60^{\circ} \mathrm{C}$ for $24 \mathrm{~h}$. Ultrathin sections were cut from the hypocotyl samples, and observed under a transmission electron microscope (FEI Tecnai 12, Hillaborough, OR, USA).

\subsection{Statistical Analysis}

Significant differences among the treatments were determined by analysis of variance (ANOVA), followed by Duncan's multiple range tests of SPSS 17.0 (IBM, Almok, New York, NY, USA) at $p \leq 0.05$.

\section{Results}

\subsection{Experiment 1}

\subsubsection{Growth, Morphological and Physiological Parameters}

Morphological parameters of cucumber seedlings were significantly affected by different SL qualities under ELI (Figure 1A-F), and this phenomenon appeared as early as the one-leaf stage (Figure 1A,B). Seedling vigor also showed significant difference as shown in Figure 1G. Under SL treatment, the variation in length of shoot, first internode and hypocotyl showed a similar response pattern (Figure 1A,D,E). Typically, RB, R and RG exhibited inhibitory effects on elongation of the first internode and hypocotyl, while $\mathrm{G}$ significantly promoted hypocotyl elongation as compared with $\mathrm{CK}$ (Figure 1D,E). In comparison with CK, the length of the hypocotyl and first internode decreased by $25 \%$ and $40 \%$ under RB (Figure 1D,E). A reverse response pattern was observed in stem diameter, 
the highest stem diameter was observed in R, RB and RG, followed by RGB, B and GB (Figure 1B). A significantly bigger leaf area showed in RG, followed by RGB, R, RB and B, and then GB, CK and $G$ (Figure 1C). Seedling shoot fresh weight and dry weight showed a similar response pattern to supplemental light quality as stem diameter (Table 1).

Seedling index of cucumber seedlings grown under RB, RG and R treatments increased more than three-fold higher than those under CK (Figure 1F). Generally, supplement of monochromatic red light or dichromatic containing red light effectively suppressed hypocotyl elongation, induced stem thickening and higher biomass production. However, $G$ could restrict growth, resulted in an excessively thin stem, long hypocotyl, the lowest leaf area, as well as the lowest seedling index among all the treatments.
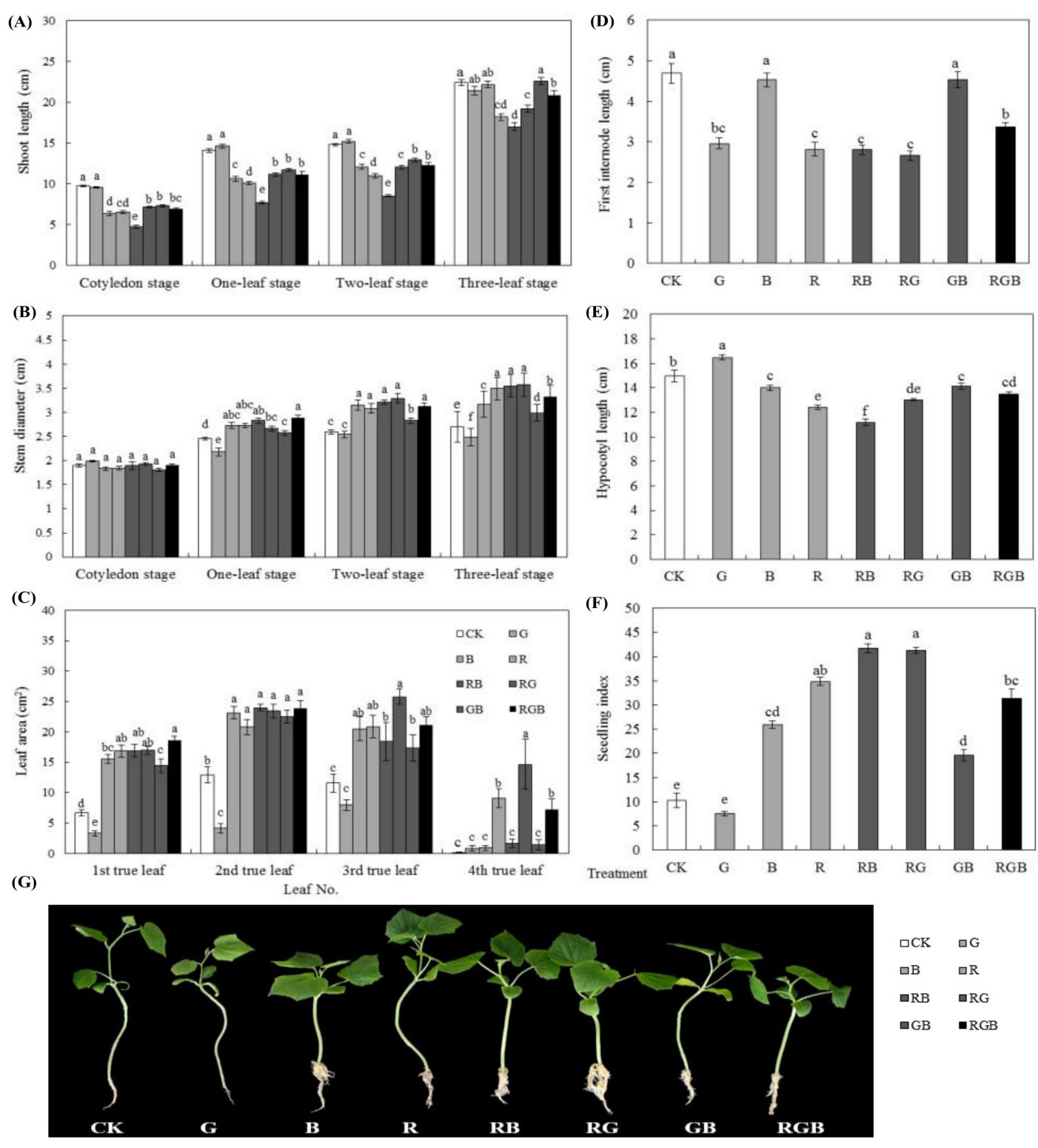

Figure 1. Effects of supplemental light quality on morphological parameters of cucumber seedlings under extremely low irradiance (ELI), including shoot length (A), stem diameter (B), leaf area (C), first internode length (D), hypocotyl length (E), seedling index (F) and growth vigor of cucumber seedlings $(\mathbf{G})$ in experiment 1 . Different letters indicate statistically significant differences among treatments $(p \leq 0.05)$. Error bars show SE $(n=24)$. 
Table 1. Effects of the different supplemental lighting treatments on biomass of shoot and root, physiological parameters of cucumber seedlings under extremely low irradiance.

\begin{tabular}{|c|c|c|c|c|c|c|c|c|c|}
\hline \multirow{2}{*}{ Treatment } & \multicolumn{3}{|c|}{ Fresh Weight (g.Plant ${ }^{-1}$ ) } & \multicolumn{3}{|c|}{ Dry Weight (g.Plant ${ }^{-1}$ ) } & \multirow{2}{*}{$\begin{array}{c}\text { Chlorophyll } \\
\text { Content }\left(\mathrm{mg}^{-1} \mathrm{~g}^{-1}\right)\end{array}$} & \multirow{2}{*}{$\begin{array}{l}\text { Soluble Sugar } \\
\text { Content }\left(\mathrm{mg}^{\left.-\mathrm{g}^{-1}\right)}\right.\end{array}$} & \multirow{2}{*}{$\begin{array}{l}\text { Soluble Protein } \\
\text { Content }\left(\mathrm{mg}^{-\mathrm{g}^{-1}}\right.\end{array}$} \\
\hline & Shoot & Root & Total & Shoot & Root & Total & & & \\
\hline CK & $1.85 \pm 0.15 \mathrm{~d}$ & $0.08 \pm 0.05 \mathrm{e}$ & $1.94 \pm 0.16 \mathrm{e}$ & $0.08 \pm 0.03 \mathrm{~d}$ & $0.003 \mathrm{c}$ & $0.09 \pm 0.03 \mathrm{~d}$ & $1.88 \pm 0.01 \mathrm{~d}$ & $2.07 \pm 0.03 \mathrm{~d}$ & $3.66 \pm 0.16 b c$ \\
\hline $\mathrm{G}$ & $1.49 \pm 0.06 \mathrm{e}$ & $0.03 \pm 0.02 \mathrm{e}$ & $1.52 \pm 0.06 \mathrm{f}$ & $0.06 \pm 0.01 \mathrm{~d}$ & $0.003 \mathrm{~d}$ & $0.06 \pm 0.01 \mathrm{~d}$ & $1.46 \pm 0.03 \mathrm{e}$ & $2.13 \pm 0.03 \mathrm{~d}$ & $3.07 \pm 0.09 \mathrm{~d}$ \\
\hline $\mathrm{B}$ & $3.15 \pm 0.40 \mathrm{~b}$ & $0.15 \pm 0.01 \mathrm{~d}$ & $3.3 \pm 0.40 \mathrm{~cd}$ & $0.16 \pm 0.02 \mathrm{abc}$ & $0.01 \mathrm{c}$ & $0.17 \pm 0.02 b c$ & $2.39 \pm 0.01 \mathrm{a}$ & $3.46 \pm 0.15 b$ & $3.65 \pm 0.09 b c$ \\
\hline $\mathrm{R}$ & $3.17 \pm 0.52 b$ & $0.26 \pm 0.05 c$ & $3.43 \pm 0.51 b c$ & $0.15 \pm 0.04 \mathrm{bc}$ & $0.017 \mathrm{bc}$ & $0.17 \pm 0.05 b c$ & $2.41 \pm 0.02 \mathrm{a}$ & $3.36 \pm 0.04 \mathrm{~b}$ & $3.16 \pm 0.03 \mathrm{~d}$ \\
\hline RB & $3.21 \pm 0.23 b$ & $0.48 \pm 0.12 \mathrm{a}$ & $3.58 \pm 0.11 b c$ & $0.17 \pm 0.01 \mathrm{abc}$ & $0.027 \mathrm{a}$ & $0.19 \pm 0.00 \mathrm{ab}$ & $2.16 \pm 0.02 b$ & $4.16 \pm 0.11 \mathrm{a}$ & $3.79 \pm 0.12 b$ \\
\hline RG & $3.76 \pm 0.28 \mathrm{a}$ & $0.28 \pm 0.06 c$ & $4.05 \pm 0.23 \mathrm{a}$ & $0.19 \pm 0.06 a$ & $0.02 \mathrm{~b}$ & $0.21 \pm 0.06 \mathrm{a}$ & $1.89 \pm 0.04 \mathrm{~d}$ & $3.37 \pm 0.16 b$ & $3.48 \pm 0.49 c$ \\
\hline GB & $2.81 \pm 0.19 c$ & $0.22 \pm 0.06 c$ & $3.03 \pm 0.22 \mathrm{~d}$ & $0.14 \pm 0.03 c$ & $0.013 \mathrm{c}$ & $0.15 \pm 0.03 c$ & $2.37 \pm 0.04 \mathrm{a}$ & $2.93 \pm 0.03 c$ & $4.46 \pm 0.44 \mathrm{a}$ \\
\hline RGB & $3.56 \pm 0.16 \mathrm{a}$ & $0.38 \pm 0.07 b$ & $3.94 \pm 0.14 \mathrm{a}$ & $0.17 \pm 0.01 \mathrm{abc}$ & $0.02 \mathrm{~b}$ & $0.19 \pm 0.00 \mathrm{ab}$ & $2.02 \pm 0.02 c$ & $3.02 \pm 0.15 c$ & $3.65 \pm 0.67 b c$ \\
\hline
\end{tabular}

Note: presented values are means \pm SE. Different letters in the same column indicate significant differences $(p \leq 0.05, n=24)$. 
Except for G, cucumber seedling biomass, chlorophyll content and soluble sugar content were all promoted under the other supplemental light treatments (Table 1). The fresh weight of cucumber seedlings grown under RG and RGB was significantly higher than the other treatments, and RG, RB and RGB produced significantly higher dry weight. Seedlings grown under R, B and GB had significantly higher chlorophyll content than those under other treatments. RB treatment significantly stimulated soluble sugar accumulation in leaves, which were two-fold more than CK, followed by B, RG, and R. To compare with CK, soluble protein content increased significantly in GB treatment, but significantly decreased in $G$ and $R$ treatments, and there was no significant difference among the other treatments.

\subsubsection{Photosynthetic Characteristics}

The $P_{n}$ was significantly enhanced by SL except the $G$ treatment. The $P_{n}$ of seedlings grown under $\mathrm{RB}$ was $29 \%$ significantly higher than $\mathrm{B}$, whereas there were no differences between $\mathrm{RB}$ and $\mathrm{R}$; however, the $P_{n}$ was significantly reduced by adding $G$ in $R$ or RB (Figure 2A). The $T_{s}$ was increased by adding $G$ in $B$ or RG (Figure $2 D$ ). Both the $T_{s}$ and $G_{s}$ were increased by the combination of $G$ and $B$ (Figure 2B,D). Generally, $R$ and RB was more effective in enhancing the $P_{n}$ than the other light treatments. $G$ reduced the $P_{n}$ in the form of dichromatic light, while it enhanced $G_{s}$ and $T_{s}$ when combined with B for cucumber seedlings grown in ELI. Ci was not affected by SL (Figure 2C).
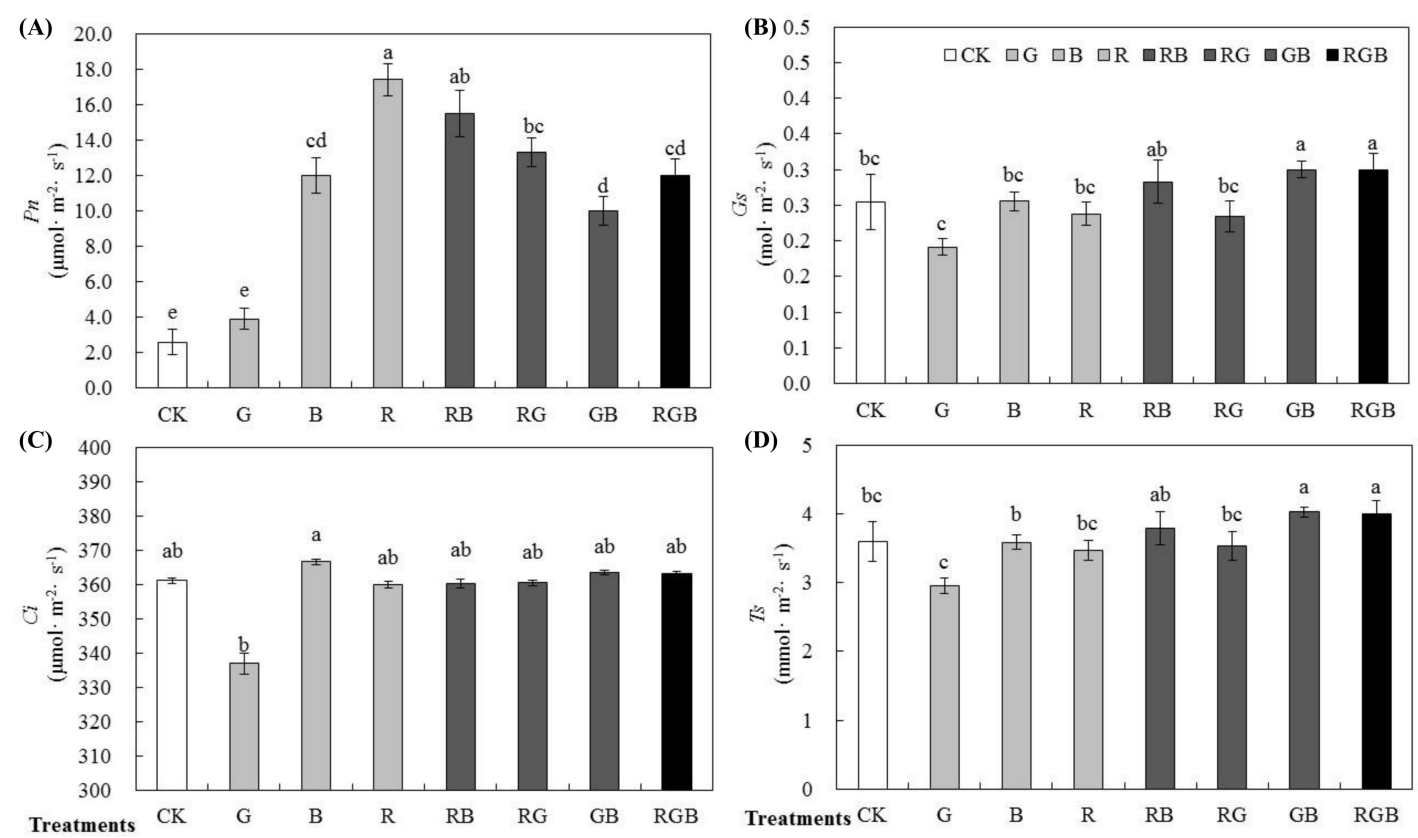

Figure 2. Effects of supplemental light quality on net photosynthetic rates $\left(\mathrm{A}, \mathrm{P}_{\mathrm{n}}\right)$, stomatal conductance $\left(\mathbf{B}, \mathrm{G}_{\mathrm{S}}\right)$, intercellular $\mathrm{CO}_{2}$ concentration $\left(\mathbf{C}, \mathrm{C}_{\mathrm{i}}\right)$, and transpiration rate $\left(\mathbf{D}, \mathrm{T}_{\mathrm{S}}\right)$ of cucumber seedlings under extremely low irradiance. Different letters indicate statistically significant differences among treatments $(p \leq 0.05)$. Error bars show SE $(n=24)$.

\subsection{Experiment 2}

\subsubsection{Growth, Morphological and Physiological Parameters}

Similar to experiment one, morphological parameters of cucumber seedlings were significantly affected by different SL under ELI as early as the one-leaf seedling stage (Figure 3A-D) in experiment two. Seedling vigor also showed significant difference as shown in Figure 3G. All SL treatments prominently suppressed the elongation of hypocotyl and shoot (Figure $3 \mathrm{~A}, \mathrm{C}$ ), promoted the stem thickening and leaf expansion (Figure 3B,D), and increased the number of leaves of cucumber seedlings (Figure 3E). There was no significant difference in leaf number and hypocotyl length among SL 
treatments (Figure 3C,E). Stem diameter significantly increased in 1R2B, when light intensity increased from $50 \mu \mathrm{mol} \cdot \mathrm{m}^{-2} \cdot \mathrm{s}^{-1}$ to $75 \mu \mathrm{mol} \cdot \mathrm{m}^{-2} \cdot \mathrm{s}^{-1}$ in two-leaf and three-leaf stages, whereas this was not observed in 1R1B (Figure 3B). Leaf area under $75 \mu \mathrm{mol} \cdot \mathrm{m}^{-2} \cdot \mathrm{s}^{-1}$ light intensity was significantly bigger than $50 \mu \mathrm{mol} \cdot \mathrm{m}^{-2} \cdot \mathrm{s}^{-1}$ during two-leaf stage. However, during three-leaf stage, the total leaf area significantly increased by $35 \%$ in 1R2B-75 as compared to 1R1B-50, whereas there was no significant difference among 1R1B-50, 1R1B-75 and 1R1B-75 (Figure 3D). Leaf area increased both when the blue light proportion and light intensity increased in cucumber seedlings under ELI during the three-leaf stage.
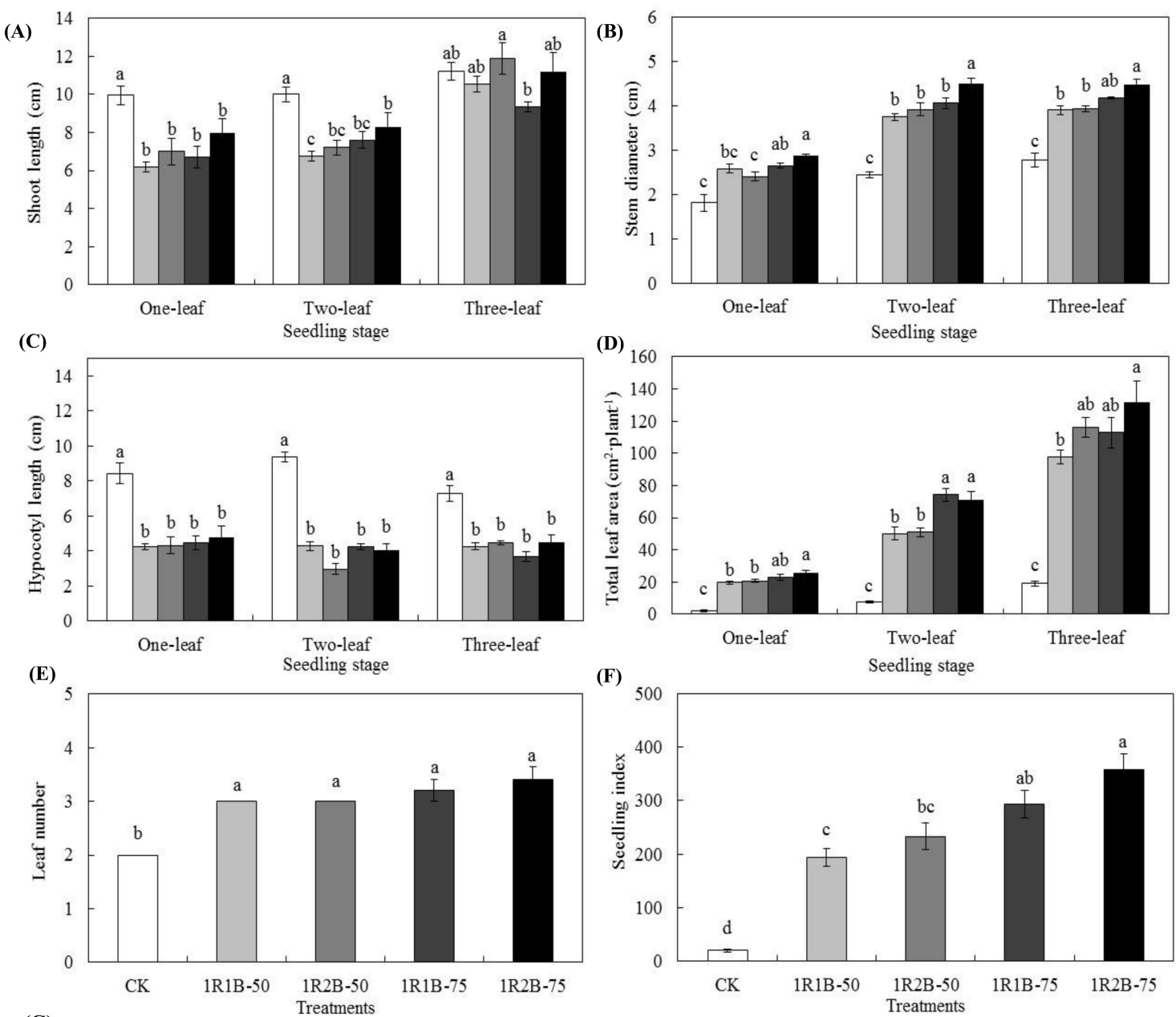

(G)

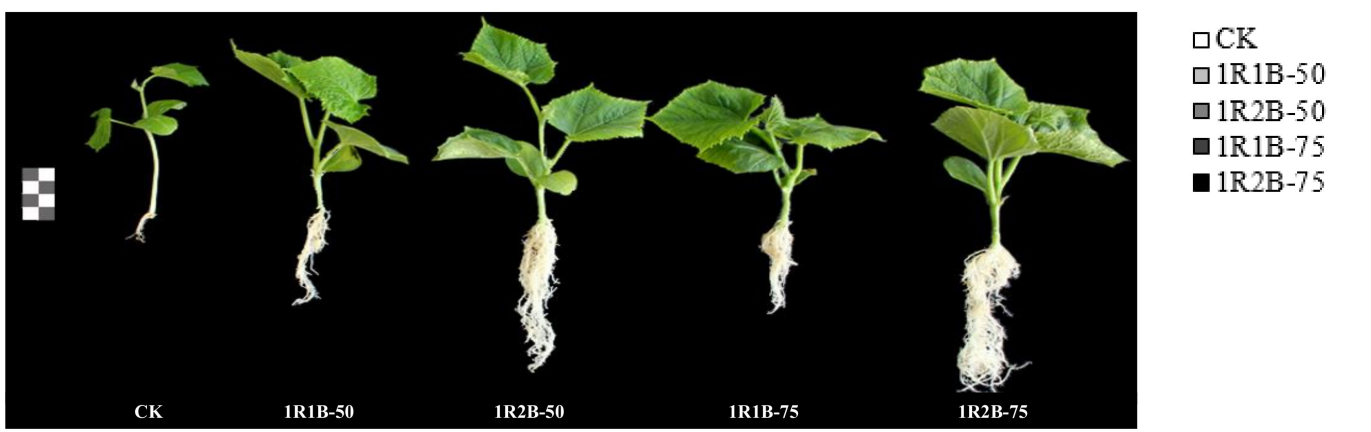

Figure 3. Effects of blue and red light-emitting diodes (LED) light (RB) ratio and intensity of supplemental light on morphological parameters of cucumber seedlings under extremely low irradiance, including shoot length (A), stem diameter (B), hypocotyl length (C), total leaf area (D), leaf number (E), seedling index $(\mathbf{F})$ and growth vigor of cucumber seedlings $(\mathbf{G})$ in experiment 2. Different letters indicate statistically significant differences among treatments $(p \leq 0.05)$. Error bars show SE $(n=24)$. 
Seedling index exhibited a similar response tendency to light treatments as stem diameter. Both increasing blue light proportion and SL intensity could increase seedling index, while one of the factors did not have the same effects (Figure 3F). To compare with 1R1B-50, seedling index increased by $51 \%$ and $85 \%$ in $1 \mathrm{R} 1 \mathrm{~B}-75$ and $1 \mathrm{R} 2 \mathrm{~B}-75$, respectively. There was no significant difference between 1R1B-50 and 1R2B-50. In this study, increasing light intensity was more effective than increasing blue light proportion to enhance seedling index.

Shoot biomass of cucumber seedling significantly increased under SL, in which both increasing blue light proportion and light intensity could increase shoot biomass, while one of the factors did not have these increased effects (Table 2). In comparison with CK, shoot fresh and dry mass increased by about 4.8-fold, and nine-fold in 1R2B-75, respectively, and root fresh mass and dry mass increased by about 17.2- and 11-fold. At the same SL intensity level, the root-shoot ratio of cucumber seedlings significantly increased with the increasing of blue light proportion under the ELI (Table 2). However, increasing light intensity had no effect on the root-shoot ratio.

As compared with CK, root activity of cucumber seedlings was significantly promoted in 1R2B-50, 1R1B-75 and 1R2B-75 treatments (Table 2). At the same SL intensity, root activity significantly increased with the increasing of blue light proportion. Furthermore, root activity significantly increased with the increasing of light intensity, ranging from $50 \mu \mathrm{mol} \cdot \mathrm{m}^{-2} \cdot \mathrm{s}^{-1}$ to $75 \mu \mathrm{mol} \cdot \mathrm{m}^{-2} \cdot \mathrm{s}^{-1}$ at both light qualities. Root activity increased by $78 \%$ under $1 \mathrm{R} 2 \mathrm{~B}$ as compared with $1 \mathrm{R} 1 \mathrm{~B}$ at $50 \mu \mathrm{mol} \cdot \mathrm{m}^{-2} \cdot \mathrm{s}^{-1}$ and increased by $26 \%$ at $70 \mu \mathrm{mol} \cdot \mathrm{m}^{-2} \cdot \mathrm{s}^{-1}$, respectively (Table 2 ). In this study, the root activity of cucumber seedlings was significantly enhanced by increasing blue light proportion or light intensity under the ELI.

The chlorophyll content in cucumber seedling leaves was reduced by SL, which reduced by decreasing the blue light proportion. Accumulation of soluble sugar in seedling leaf was stimulated by SL, which increased with the increasing of supplemental light intensity from $50 \mu \mathrm{mol} \cdot \mathrm{m}^{-2} \cdot \mathrm{s}^{-1}$ to $75 \mu \mathrm{mol} \cdot \mathrm{m}^{-2} \cdot \mathrm{s}^{-1}$, while the proportion of blue light had no effect on soluble sugar accumulation. Except for 1R2B-75 treatment, the soluble protein content was significantly reduced under other supplemental light treatments as compared with CK. 
Table 2. Effects of RB ratio and intensity of supplemental light on biomass and physiological parameters of cucumber seedlings under extremely low irradiance.

\begin{tabular}{|c|c|c|c|c|c|c|c|c|c|}
\hline \multirow{2}{*}{ Treatment } & \multicolumn{2}{|c|}{ Fresh Weight (g.Plant $\left.{ }^{-1}\right)$} & \multicolumn{2}{|c|}{ Dry Weight (g.Plant ${ }^{-1}$ ) } & \multirow{2}{*}{$\begin{array}{c}\text { Ratio } \\
\text { (Root/Shoot) }\end{array}$} & \multirow{2}{*}{$\begin{array}{l}\text { Root Activity } \\
\left(\mathrm{mg}^{-1} \cdot \mathrm{h}^{-1}\right)\end{array}$} & \multirow{2}{*}{$\begin{array}{c}\text { Chlorophyll } \\
\text { Content }\left(\mathrm{mg} \cdot \mathrm{g}^{-1}\right)\end{array}$} & \multirow{2}{*}{$\begin{array}{l}\text { Soluble Sugar } \\
\text { Content }\left(\mathrm{mg} \cdot \mathrm{g}^{-1}\right)\end{array}$} & \multirow{2}{*}{$\begin{array}{c}\text { Soluble Protein } \\
\text { Content }\left(\mathrm{mg}^{\left.-\mathrm{g}^{-1}\right)}\right.\end{array}$} \\
\hline & Shoot & Root & Shoot & Root & & & & & \\
\hline CK & $1.42 \pm 0.1 \mathrm{c}$ & $0.10 \pm 0.0 \mathrm{c}$ & $0.08 \pm 0.0 \mathrm{c}$ & $0.01 \pm 0.00 c$ & $0.05 \pm 0.01 \mathrm{~b}$ & $59.67 \pm 0.39 c$ & $2.10 \pm 0.06 \mathrm{a}$ & $4.03 \pm 0.12 c$ & $5.73 \pm 0.09 \mathrm{a}$ \\
\hline 1R1B-50 & $4.70 \pm 0.2 b$ & $0.74 \pm 0.3 \mathrm{bc}$ & $0.47 \pm 0.1 \mathrm{~b}$ & $0.05 \pm 0.01 \mathrm{~b}$ & $0.10 \pm 0.02 b$ & $60.33 \pm 0.22 c$ & $1.70 \pm 0.00 \mathrm{c}$ & $7.77 \pm 0.15 b$ & $4.98 \pm 0.09 c$ \\
\hline 1R2B-50 & $5.70 \pm 0.3 \mathrm{ab}$ & $1.42 \pm 0.3 \mathrm{ab}$ & $0.61 \pm 0.1 \mathrm{ab}$ & $0.10 \pm 0.01 \mathrm{a}$ & $0.16 \pm 0.02 \mathrm{a}$ & $107.33 \pm 0.84 b$ & $1.85 \pm 0.01 \mathrm{~b}$ & $7.81 \pm 0.27 b$ & $5.08 \pm 0.14 b c$ \\
\hline 1R1B-75 & $5.60 \pm 0.5 \mathrm{ab}$ & $0.76 \pm 0.1 \mathrm{bc}$ & $0.60 \pm 0.1 \mathrm{ab}$ & $0.06 \pm 0.01 \mathrm{~b}$ & $0.10 \pm 0.01 \mathrm{~b}$ & $116.67 \pm 0.39 b$ & $1.82 \pm 0.04 \mathrm{~b}$ & $9.96 \pm 0.13 \mathrm{a}$ & $5.40 \pm 0.09 \mathrm{~b}$ \\
\hline 1R2B-75 & $6.80 \pm 0.6 \mathrm{a}$ & $1.82 \pm 0.3 \mathrm{a}$ & $0.79 \pm 0.1 \mathrm{a}$ & $0.12 \pm 0.02 \mathrm{a}$ & $0.16 \pm 0.02 \mathrm{a}$ & $146.67 \pm 0.85 \mathrm{a}$ & $1.87 \pm 0.03 b$ & $9.81 \pm 0.21 \mathrm{a}$ & $5.82 \pm 0.09 a$ \\
\hline
\end{tabular}

Note: presented values are means \pm SE. Different letters in the same column indicate significant differences $(p \leq 0.05, n=24)$. 


\subsubsection{Photosynthetic Characteristics and Antioxidant Enzyme Activity}

In comparison with $\mathrm{CK}, \mathrm{P}_{\mathrm{n}}$ increased by 70\% and two-fold in 1R1B-75 and 1R2B-75, respectively (Figure 4A), indicating that Pn was enhanced by increasing the proportion of blue light from $50 \%$ (1R1B) to $67 \%(1 \mathrm{R} 2 \mathrm{~B})$ when SL intensity was $75 \mu \mathrm{mol} \cdot \mathrm{m}^{-2} \cdot \mathrm{s}^{-1}$, but there was no significant difference between these two treatments. Gs was enhanced by SL, but it was reduced by increasing blue light proportion (Figure 4B). Ci increased under SL, and there were no significant differences among different SL treatments (Figure 4C). The Ts of cucumber seedlings grown under 1R2B-75 was significantly increased by $22 \%$ as compared with CK (Figure $4 \mathrm{D})$.

Under SL, the activities of SOD and POD in cucumber seedlings significantly increased (Figure 5A,B), while CAT activities reduced (Figure 5C). Increasing blue light proportion could significantly increase activities of POD and CAT. Increasing both blue light proportion and SL intensity (1R2B-75 vs. 1R1B-50) could significantly increase activities of SOD, POD and CAT (Figure 5A-C).
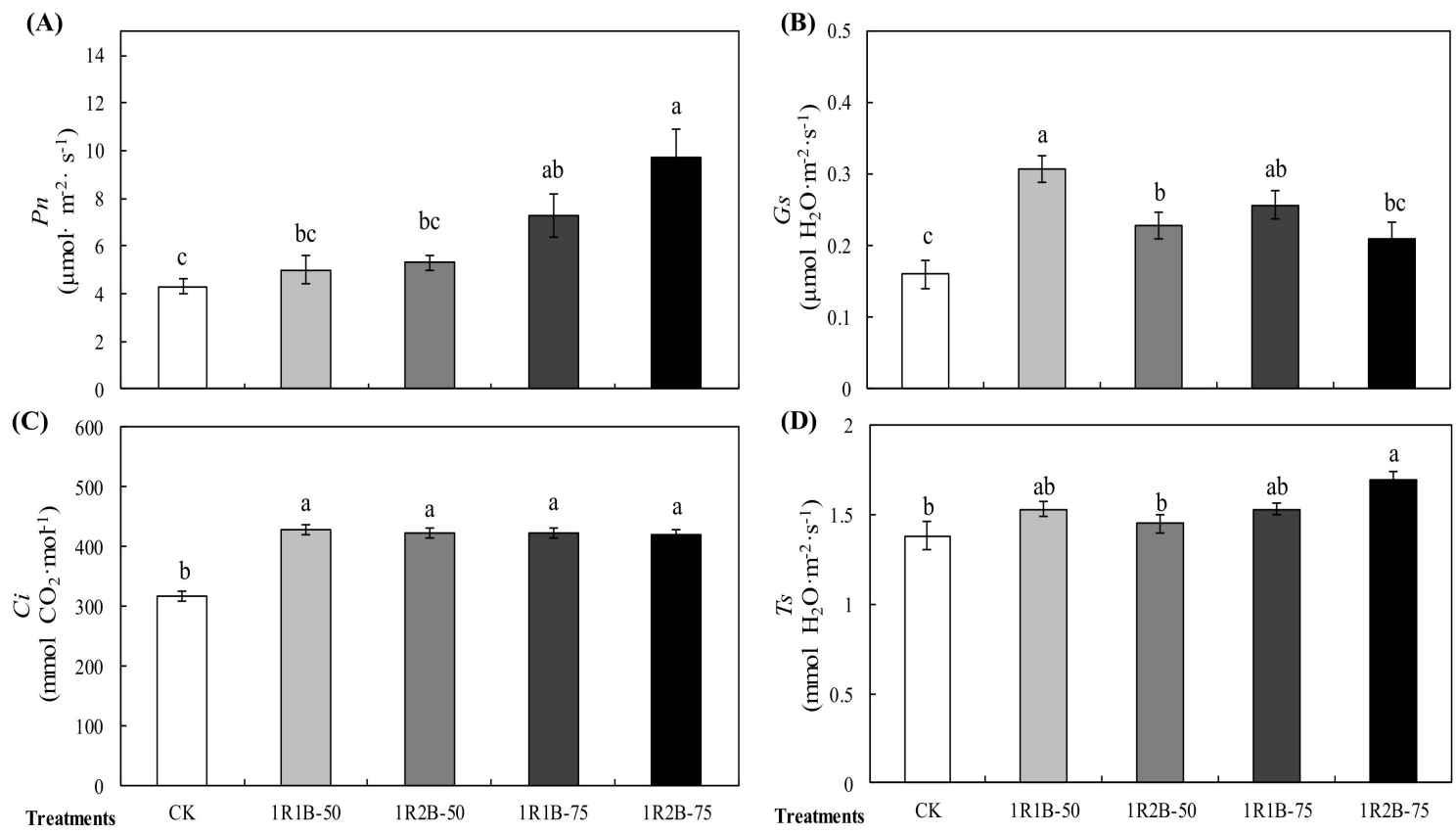

Figure 4. Effects of RB ratio and intensity of supplemental light on net photosynthetic rates $\left(A, P_{n}\right)$, stomatal conductance $\left(\mathbf{B}, \mathrm{G}_{\mathrm{S}}\right)$, intercellular $\mathrm{CO}_{2}$ concentration $\left(\mathbf{C}, \mathrm{C}_{\mathrm{i}}\right)$, and transpiration rate $\left(\mathbf{D}, \mathrm{T}_{\mathrm{s}}\right)$ of cucumber seedlings under extremely low irradiance. Different letters indicate statistically significant differences among treatments (ANOVA, $p \leq 0.05$ ).

\subsubsection{Anatomical Structure of Hypocotyl and Mesophyll}

Leaf anatomical structure shown in Figure 6A. The thickness of leaf, palisade tissue (Figure 6B) and spongy parenchyma (Figure 6C) of cucumber seedlings was significantly promoted by SL. In each SL intensity of 50 or $70 \mu \mathrm{mol} \cdot \mathrm{m}^{-2} \cdot \mathrm{s}^{-1}$, palisade parenchyma thickness increased but spongy parenchyma thickness reduced with increasing blue light proportion from 50\% (1R1B) to 67\% (1R2B) (Figure 6D).

Average cell area of the vertical (Figure 7A) or horizontal section (Figure 7B) in hypocotyl was enlarged by SL, in which the hypocotyl cell area of the vertical section was reduced by increasing blue light proportion and increasing light intensity. However, blue light proportion or light intensity had no effect on the cell area of the horizontal section (Figure 7C). 


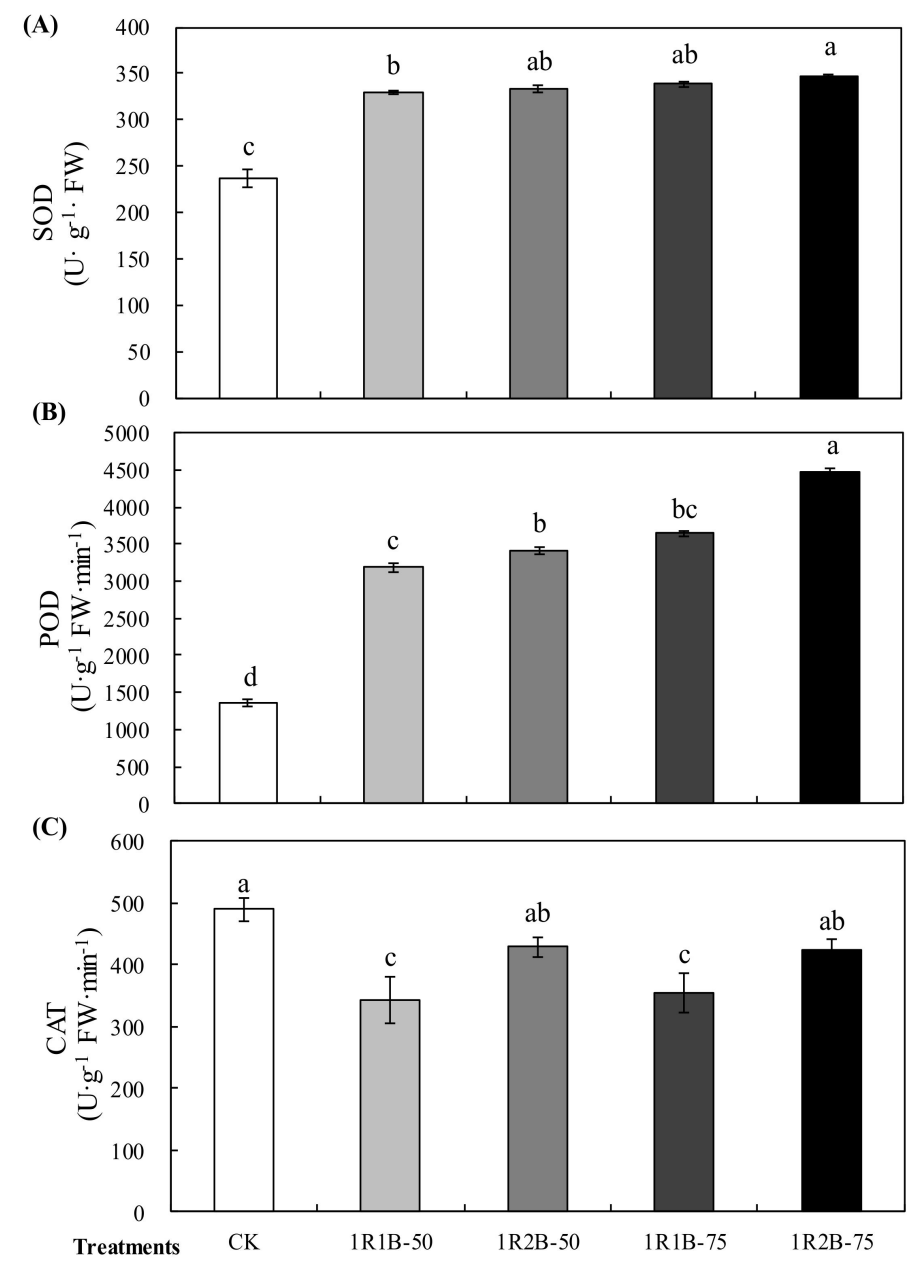

Figure 5. Effects of RB ratio and intensity of supplemental light on antioxidant enzyme activity of cucumber seedlings under extremely low irradiance. Sodium dismutase (SOD) (A), peroxidase (POD) (B) and catalase (CAT) (C). Different letters indicate statistically significant differences among treatments (ANOVA, $p \leq 0.05)$.

(A)

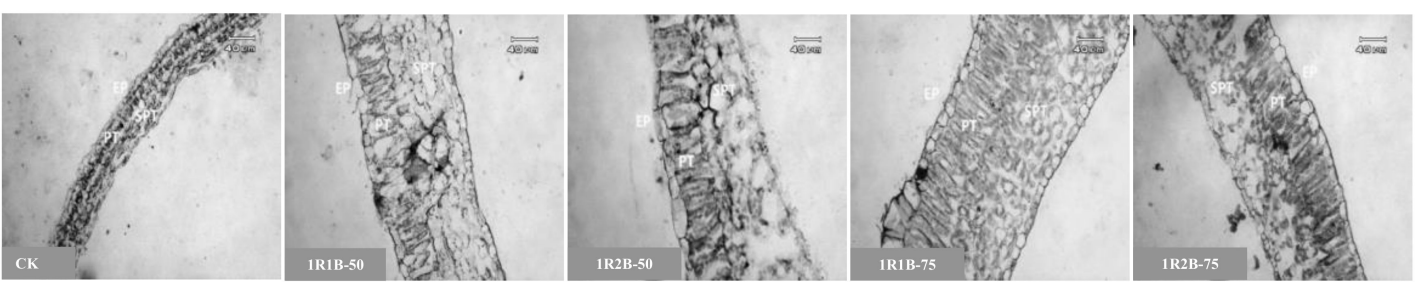

(B)
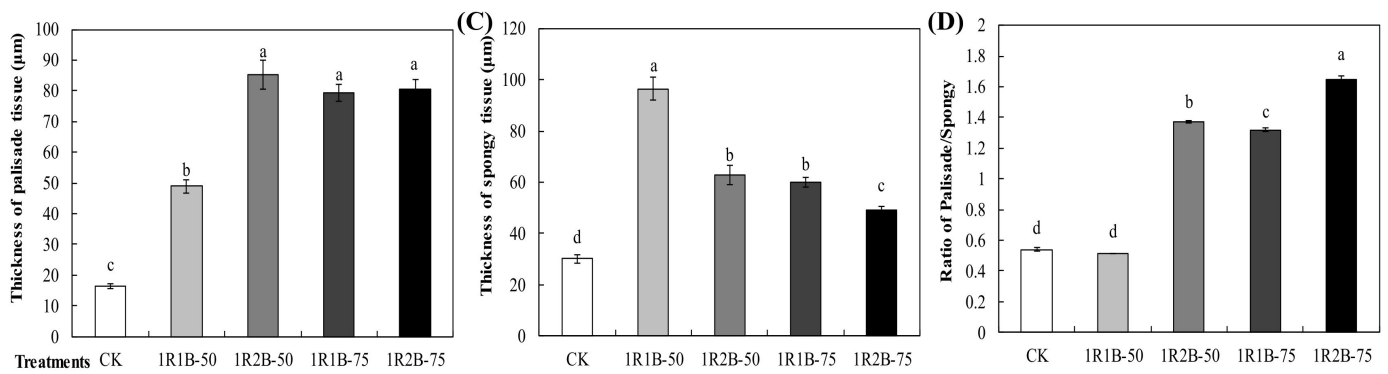

Figure 6. Effects of RB ratio and intensity of supplemental light on cucumber seedling leaf anatomical structure (PT: palisade tissue, SPT: spongy tissue. (A)), palisade thickness (B), spongy thickness (C) and ratio of palisade/Spongy (D). Different letters indicate statistically significant differences among treatments (ANOVA, $p \leq 0.05$ ). 
(A)
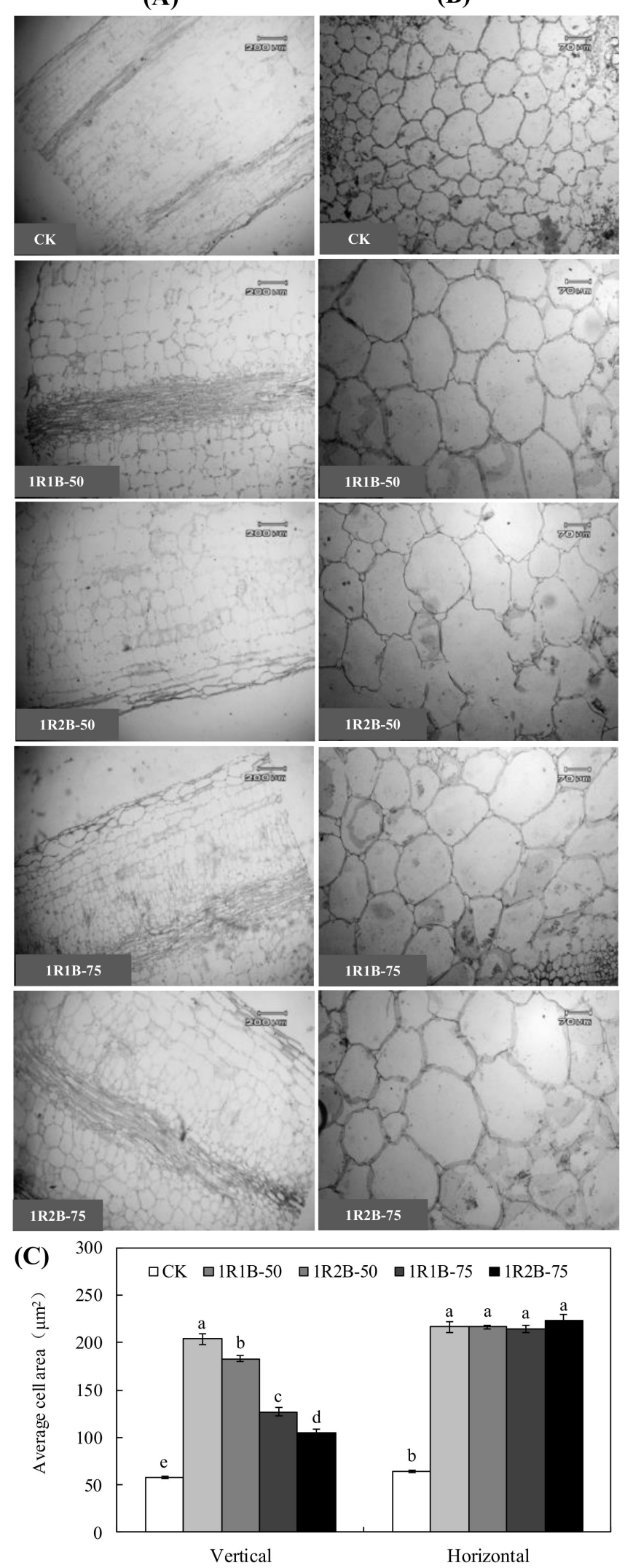

Figure 7. Microstructure from hypocotyl cells in cucumber seedlings grown under different light treatments. Vertical cut $40 \times($ A), horizontal cut $100 \times($ B $)$, average cell area (C). Different letters indicate statistically significant differences among treatments (ANOVA, $p \leq 0.05$ ). 
The chloroplasts of CK exhibited an oblate and long shape, containing less starch granules and more basal granules, which was clearly visible and assembled distinctively. In contrast, the chloroplast exhibited an elliptic shape under SL, containing less basal granules and more starch granules (Figure 8A). In comparison with CK, the mitochondria in the leaf of seedlings under SL were bigger and contained more inclusions. There were no significant differences in the size of mitochondria under SL treatments, and the internal structure was clearer than those in CK (Figure 8B).

(A)

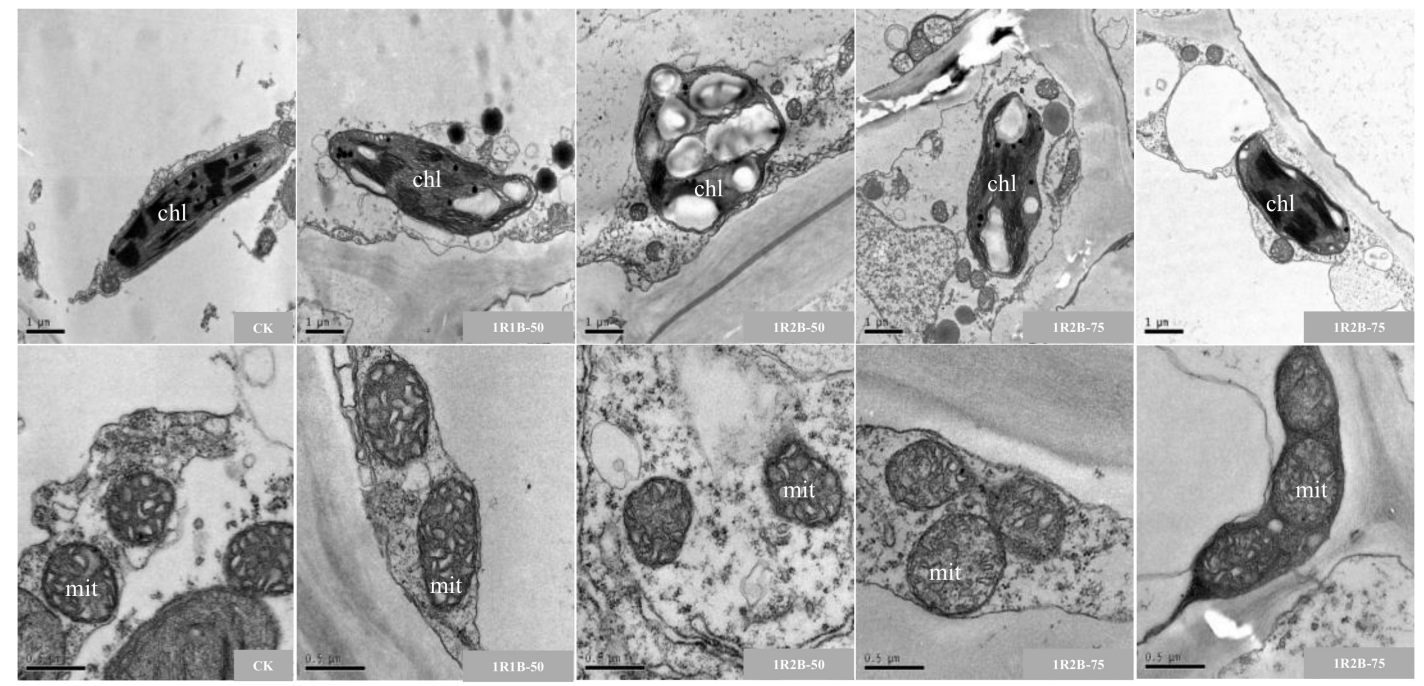

Figure 8. Ultrastructure of chloroplast (chl, A) and mitochondria (mit, B) from leaf cells in cucumber seedlings grown under different light treatments. CK, extremely low irradiance $\left(0-35 \mu \mathrm{mol} \cdot \mathrm{m}^{-2} \cdot \mathrm{s}^{-1}\right.$ PPFD).

\section{Discussion}

Hypocotyl elongation regulated by light quality has been documented in several studies. Hernández and Kubota [5] reported that 100\% red light was preferred for cucumber seedlings, and additional blue light was not beneficial for SL in greenhouses. Monochromatic red SL resulted in a shorter hypocotyl length than monochromatic blue SL in cucumber seedlings [5] and tomato seedlings [27]. However, several studies have shown that red light was more effective at elongating stem height, and red and green light stimulated stem elongation, while blue light inhibited stem elongation in chrysanthemums [28] and tomatoes [14].

This study indicates that R SL or dichromatic containing R light (RB and RG) significantly promoted the growth of cucumber seedlings, as demonstrated by the suppressed hypocotyl and first internode (Figure 1D,E), combined with higher biomass accumulation (Table 1). Furthermore, 31\% less plant height was found under 50B:50R treatment than under 100B treatment for tomato seedlings [14]. Red light has the highest relative quantum amount in the PAR spectrum [8], and absorption peaks of chlorophyll are closer to the red spectrum [9]. In the presence of red light, the Pfr absorbing form was the most abundant, which suppressed stem elongation; however, when red light was removed, the blue $(455 \mathrm{~nm})$ light made the Pr absorbing form more abundant and consequently lowered the inhibition of hypocotyl elongation [29].

In this study, the highest chlorophyll content was observed in R, followed by $B, G B$ and RB (Table 1), while $P_{n}$ showed a similar response pattern to chlorophyll content (Figure 2A). R and RB showed promotion effects on $P_{n}$, while G, B, GB and RGB exhibited inhibitory effects on $P_{n}$. Soluble sugar accumulation was also promoted in leaves under $\mathrm{RB}$, which reached up to two-fold more than $\mathrm{CK}$ (Table 1). Higher leaf photosynthetic rates under R and RB might be associated with higher chlorophyll content. The sunlight PAR spectrum $(400-700 \mathrm{~nm})$ contains about $31 \%$ of blue light on the energy basis 
(400-500 nm) out of photosynthetically active radiation [12]. Blue light was essential for enhancing photosynthetic electron transport and the activities of photosystem II and I in cucumber leaves [12].

Both $G_{s}$ and $T_{s}$ significantly increased with the combination of $G$ and $B$ or $B$ and RG light as compared with monochromatic light (Figure 2B,D). In addition, accumulation of soluble protein was also promoted by GB (Table 1). Green light is known to increase hypocotyl length in several plant species [30,31]. The effect of green light is similar to blue light [32], the positive response of the plant photosynthetic capacity and phytochemicals to green light depend on light quantity $[33,34]$. In this study, adding $\mathrm{G}$ to $\mathrm{B}$ or RB showed significantly increased shoot height and decreased seedling index (Figure 1A,F), and $\mathrm{P}_{\mathrm{n}}$ also decreased. Generally, monochromatic or additional green light was not beneficial to cucumber seedlings in the case of ELI.

Many pieces of research have shown that the combination of red and blue light has significant synergistic effects on plant growth $[5,11,15]$. In experiment one, combinations of $\mathrm{R}$ and $\mathrm{B}$ or $\mathrm{R}$ and $\mathrm{G}$ light reversed the effect of monochromatic light on hypocotyl length and seedling index. Therefore, the combination of $\mathrm{R}$ and $\mathrm{B}$ or $\mathrm{R}$ and $\mathrm{G}$ has synergistic effects on the inhibition of elongation of hypocotyl and promotion of seedling index for cucumber seedlings in the case of ELI.

Generally, the morphological parameters and physiological characteristics of cucumber seedlings were improved by SL in experiment one, but the seedlings still exhibited spindling growth. It is well known that the response of seedling morphological parameters depends not only on the light quality, but also on the total photon flux density. Thus, different RB ratios combining SL light intensity were conducted in experiment two. RB SL prominently increased leaf number, suppressed the hypocotyl elongation and promoted the stem thickening of cucumber seedlings. As a result of the expansion of the hypocotyl cell in the horizontal section and the reduced cell area in the vertical section of cucumber seedlings grown under SL of RB (Figure 7C), the suppression of hypocotyl elongation was significantly promoted by SL treatments (Figure 3C).

In this study, stem diameter significantly increased with the increasing of light intensity in the case of 1R2B, which was not observed in 1R1B (Figure 3B). Thus, 1R2B-75 exhibited significantly higher seedling index than 1R1B-50 and 1R2B50, which is attributable to increased stem diameter and dry mass. The increasing of blue light proportion decreased tomato plant height [15]. At the same SL intensity level, root activity and root/shoot ratio of cucumber seedlings significantly increased with increasing blue light proportion in the ELI (Table 2). These results indicate that carbon metabolites distributed to roots are more than shoots under higher proportion of $B$ than R in RB. In spite of the seedling index being enhanced in 1R2B-75, increasing blue light proportion had no effect on suppressing the elongation of hypocotyl (Figure 3C), indicating that increasing the amount probably could not satisfy the required level of light intensity or R and B ratio in the ELI condition, thus a higher blue light or red light proportion should be discussed in the future research.

Blue light during growth is not only for qualitatively photosynthesis and but also quantitatively mediates leaf responses, resembling irradiance intensity [13,35]. Increasing the percentage of blue light could promote hydraulic conductance, net photosynthetic rate, stomatal conductance, and chlorophyll concentration in cucumber seedlings [11,13] and tomato seedlings [14]. In contrast, Nanya et al. [16] found that net photosynthesis rate increased with the reduction in blue light percent and increase in red light percent in tomato. In this research, $\mathrm{P}_{\mathrm{n}}$ increased by $32 \%$ with increasing proportion of blue light from $50 \%$ (1R1B) to $67 \%$ (1R2B) in the case of $75 \mu \mathrm{mol} \cdot \mathrm{m}^{-2} \cdot \mathrm{s}^{-1}$ PPFD SL, but there was no significant difference between them. Additionally, $\mathrm{P}_{\mathrm{n}}$ was significantly enhanced by increasing light intensity in the case of 1R2B, which was not observed in 1R1B. Cucumber plants showed greater stomata density, larger stomata, and consequently greater Gs under higher blue light proportion [11,13,36]. Increasing the B:R ratio increases stomata pore aperture [37-40]. Blue light increases the leaf photosynthetic pigment content [35] and improves the stomatal conductance [13]. The combination of red and blue increased leaf nitrogen accumulation [41], thereby increasing the photosynthetic rate [42]. In contrast, this research shows a trend of decreasing Gs with the decrease in R:B ratio in the case of $50 \mu \mathrm{mol} \cdot \mathrm{m}^{-2} \cdot \mathrm{s}^{-1}$ 
PPFD SL. Generally, light intensity contributed more to photosynthesis than RB ratio in the case of ELI; therefore, suitable RB ratios should be discussed in future research.

The leaf is an important organ to perceive and capture light. Light changes the anatomical structure of leaves by regulating the differentiation or arrangement of palisade and spongy cells [43]. Leaf thickness was increased nearly 1 2 times by the supplement of blue light to red light with the increase in palisade parenchyma length in pepper [44]. In this study, the thickness of the leaf, palisade parenchyma and spongy parenchyma was significantly promoted and cells of palisade and spongy were well arranged under SL. Higher blue light proportion and light intensity increased the thickness of palisade but decreased spongy parenchyma, the palisade-spongy ratio increased significantly, which indicates that the photosynthesis of the leaf was enhanced but transpiration was relatively weakened. Both light intensity and blue light proportion has a synergistic effect on leaf expansion in cucumber seedlings. Leaves with well-arranged cells of palisade and spongy, thicker palisade parenchyma and spongy parenchyma can significantly reduce transpiration, which were considered to be beneficial to the growth of the in vitro cultured plantlets [45]. In this research, the shape of chloroplast was changed by SL, which contained less basal granules and more starch granules (Figure $8 \mathrm{~A}$ ), and mitochondria were bigger, containing more inclusions as well as the internal structure being clearer under SL (Figure 8B). The chloroplast ultrastructure in cucumber seedlings was remarkably altered by blue or red light [46]. Starch in chloroplasts can be translated or utilized more easily under blue light than red light [47]. More carbohydrate content in cucumber seedlings under SL might be associated with enhanced photosynthesis and more carbohydrates.

In plant cells, the reactive oxygen species (ROS) generated via the photosynthetic electron transport pathway can attack cellular molecules, such as DNA, Rubisco, and Chlorophyll, leading to accelerated plant cell senescence processes [48]. Chloroplasts and mitochondria of plant cells are major sites for the generation of ROS under stress conditions. SOD dismutates $\mathrm{O}_{2}^{-}$into $\mathrm{H}_{2} \mathrm{O}_{2}$ in chloroplast, mitochondria and other organelles. In this study, the activity of SOD, POD and CAT of cucumber seedlings was enhanced by increasing blue light proportion and light intensity as compared to CK (Figure 5). Furthermore, seedling index showed a similar response pattern to different light treatments as SOD and POD activities, indicating that stress resistance of cucumber seedlings is also associated with seedling index under SL in the case of ELI.

\section{Conclusions}

In this study, morphological and physiological parameters of cucumber seedlings were promoted effectively by supplemental monochromatic red light or dichromatic containing red light (RB and RG) under ELI as early as the one-leaf seedling stage, as demonstrated by the suppressed length of hypocotyl and first internode, the thickening stem diameter and more biomass, higher $\mathrm{P}_{\mathrm{n}}$ and soluble sugar content. Monochromatic or additional green light was not beneficial to cucumber seedlings under ELI. Based on supplemental combined blue and red light, increasing blue light proportion and light intensity has synergistic effects on enhancing the seedling index, root activity, ratio of palisade-spongy and root-shoot of cucumber seedlings grown under ELI. Increasing light intensity was more effective than increasing blue light proportion in enhancing seedling index. Generally, 1R2B-75 might be the optimal SL to inhibit spindling growth of cucumber seedlings under ELI in protected cultivation conditions.

Author Contributions: Y.Z. and H.D. performed the experiment and participated in the data analysis. S.S. and W.S. drafted the manuscript. H.L. conceived the study and participated in its design. H.L. acquired the funding and helped to draft the manuscript. All authors have read and agreed to the published version of the manuscript.

Funding: This work was supported by the National Key Research and Development Program of China (2019YFD1001900), the Key Research and Development Program of Guangdong (2019B020214005).

Conflicts of Interest: The authors declare no conflict of interest. 


\section{References}

1. Wei, H.; Hu, J.T.; Liu, C.; Wang, M.Z.; Zhao, J.; Kang, D.; Jeong, B.R. Effect of supplementary light source on quality of grafted tomato seedlings and expression of two photosynthetic genes. Agronomy 2018, 8, 207. [CrossRef]

2. Hao, X.M.; Papadopoulos, A.P. Effects of supplemental lighting and cover materials on growth, photosynthesis, biomass partitioning, early yield and quality of greenhouse cucumber. Sci. Hortic. 1999, 80, 1-18. [CrossRef]

3. Hemming, S.; van der Braak, N.; Dueck, T.; Jongschaap, R.; Marissen, N. Filtering natural light by greenhouse covering using model simulations-more production and better plant quality by diffuse light? Acta Hortic. 2006, 711, 105-110. [CrossRef]

4. Hemming, S.; Mohammadkhani, V.; Dueck, T. Diffuse greenhouse covering materials-material technology, measurements and evaluation of optical properties. Acta Hortic. 2008, 797, 469-475. [CrossRef]

5. Hernández, R.; Kubota, C. Growth and morphological response of cucumber seedlings to supplemental red and blue photon flux ratios under varied solar daily light integrals. Acta Hortic. 2014, 956, 187-194. [CrossRef]

6. Whitelam, G.C.; Halliday, K.J. Annual Plant Reviews, Light and Plant Development; John Wiley \& Sons: Hoboken, NJ, USA, 2007; Volume 30.

7. Hayashi, M.; Inoue, S.H.; Takahashi, K.; Kinoshita, T. Immunohistochemical detection of blue light-induced phosphorylation of the plasma membrane $\mathrm{H}^{+}$-ATPase in stomatal guard cells. Plant Cell Physiol. 2011, 52, 1238-1248. [CrossRef]

8. McCree, K.J. The action spectrum, absorptance and quantum yield of photosynthesis in crop plants. Agric. Metereol. 1971, 9, 191-216. [CrossRef]

9. Heuvelink, E. Plants in Action Adaptation in Nature, Performance in Cultivation; Atwell, B.J., Kriedmann, P.E., Turnbell, C.G.N., Eds.; Macmillan Education Australia Pty Ltd.: Melbourne, Australia, 2000.

10. Folta, K.M.; Maruhnich, S.A. Green light: A signal to slow down or stop. J. Exp. Bot. 2007, 58, 3099-3111. [CrossRef]

11. Savvides, A.; Fanourakis, D.; van Ieperen, W. Co-ordination of hydraulic and stomatal conductances across light qualities in cucumber leaves. J. Exp. Bot. 2012, 63, 1135-1143. [CrossRef]

12. Miao, Y.X.; Wang, X.Z.; Gao, L.H.; Chen, Q.Y.; Mei, Q.U. Blue light is more essential than red light for maintaining the activities of photosystem II and I and photosynthetic electron transport capacity in cucumber leaves. J. Integr. Agric. 2016, 15, 87-100. [CrossRef]

13. Hogewoning, S.W.; Trouwborst, G.; Maljaars, H.; Poorter, H.; van Leperen, W.; Harbinson, J. Blue light dose-responses of leaf photosynthesis, morphology, and chemical composition of Cucumis sativus grown under different combinations of red and blue light. J. Exp. Bot. 2010, 61, 3107-3117. [CrossRef]

14. Liu, X.Y.; Chang, T.T.; Guo, S.R.; Xu, Z.G.; Li, J. Effects of different light quality of LED on growth of LED on growth and photosynthetic characters in cherry tomato seedlings. Acta Hortic. 2011, 907, 325-330. [CrossRef]

15. Hernández, R.; Kubota, C. Tomato seedling growth and morphological responses to supplemental LED lighting Red:Blue rations under varied daily solar light integrals. Acta Hortic. 2012, 956, 187-194. [CrossRef]

16. Nanya, K.; Ishigami, Y.; Hikosaka, S.; Goto, E. Effects of blue and red light on stem elongation and flowering of tomato seedlings. Acta Hortic. 2012, 956, 261-266. [CrossRef]

17. Li, Y.M.; Zheng, Y.J.; Tan, X.; Pan, Y.; Liu, H.C. Effects of different LED supplemental lighting on growth of tomato and cucumber seedlings. China Illum. Eng. J. 2016, 27, 68-71. (In Chinese)

18. Song, J.L.; Cao, K.; Hao, Y.W.; Song, S.W.; Su, W.; Liu, H.C. Hypocotyl elongation is regulated by supplemental blue and red light in cucumber seedling. Gene 2019, 707, 117-125. [CrossRef]

19. Zhang, X.; Huang, G.; Bian, X.; Zhao, Q. Effects of root interaction and nitrogen fertilization on the chlorophyll content, root activity, photosynthetic characteristics of intercropped soybean and microbial quantity in the rhizosphere. Plant Soil Environ. 2013, 59, 80-88. [CrossRef]

20. Porra, R.J.; Thompson, W.A.; Kriedemann, P.E. Determination of accurate extinction coefficients and simultaneous equations for assaying chlorophylls a and bextracted with four different solvents: Verification of the concentration of chlorophyll standards by atomic absorption spectroscopy. Biochim. Biophys. Acta (BBA) Bioenerg. 1989, 975, 384-394. [CrossRef]

21. Bradford, M.M. A rapid and sensitive method for the quantitation of microgram quantities of protein utilizing the principle of protein-dye binding. Anal. Biochem. 1976, 72, 248-250. [CrossRef] 
22. Yemm, E.W.; Willis, A.J. The estimation of carbohydrates in plant extracts by anthrone. Biochem. J. 1954, 57, 508-514. [CrossRef]

23. Giannopolitis, C.N.; Ries, S.K. Purification and quantitative relationship with water soluble protein in seedling. Plant Physiol. 1977, 59, 315-318. [CrossRef] [PubMed]

24. Kochba, J.; Lavee, S.; Spiegel-Roy, P. Differences in peroxidase activity and isoenzymes in embryogenic and non-embryogenic 'Shamouti' orange ovular callus lines. Plant Cell Physiol. 1977, 18, 463-467. [CrossRef]

25. Cakmak, I.; Marschner, H. Magnesium deficiency and high light intensity enhance activities of superoxide dismutase, ascorbate peroxidase, and glutathione reductase in bean leaves. Plant Physiol. 1992, 98, 1222-1227. [CrossRef]

26. Naija, S.; Elloumi, N.; Jbir, N.; Ammar, S.; Kevers, C. Anatomical and biochemical changes during adventitious rooting of apple rootstocks MM 106 cultured in vitro. Comptes Rendus Biol. 2008, 331, 518-525. [CrossRef]

27. Kim, E.Y.; Park, S.A.; Park, B.J.; Lee, Y.; Oh, M.M. Growth and antioxidant phenolic compounds in cherry tomato seedlings grown under monochromatic light-emitting diodes. Hort. Environ. Biotechnol. 2014, 55, 506-513. [CrossRef]

28. Jeong, S.W.; Park, S.; Jin, J.S.; Seo, O.N.; Kim, G.S.; Kim, Y.H. Influences of four different light-emitting diode lights on flowering and polyphenol variations in the leaves of chrysanthemum. J. Agric. Food Chem. 2012, 60, 9793-9800. [CrossRef]

29. Sager, J.C.; Smith, W.O.; Edwards, J.L.; Cyr, K.L. Photosynthetic efficiency and phytochrome photoequilibria determination using spectral data. Trans. ASABE 1988, 31, 1882-1889. [CrossRef]

30. Bouly, J.P.; Schleicher, E.; Dionisio-Sese, M.; Vandenbussche, F.; van Der Straeten, D.; Bakrin, N. Cryptochrome blue-light photoreceptors are activated through interconversion of flavin redox states. J. Biol. Chem. 2007, 282, 9383-9391. [CrossRef]

31. Wang, Y.; Folta, K.M. Contributions of green light to plant growth and development. Am. J. Bot. 2013, 100, 70-78. [CrossRef]

32. Swartz, T.E.; Corchnoy, S.B.; Christie, J.M.; Lewis, J.W.; Szundi, I.; Briggs, W.R. The photocycle of a flavinbinding domain of the blue light photoreceptor phototropin. J. Biol. Chem. 2001, 276, 493-500. [CrossRef]

33. Baroli, I.M.; Dean, P.G.; Badger, M.R.; Caemmerer, S.V. The contribution of photosynthesis to the red light response of stomatal conductance. Am. Soc. Plant Biol. 2008, 146, 737-747. [CrossRef] [PubMed]

34. Hogewoning, S.W.; Douwstra, P.; Trouwborst, G.; van Ieperen, W.; Harbinson, J. An artificial solar spectrum substantially alters plant development compared with usual climate room irradiance spectra. J. Exp. Bot. 2010, 61, 1267-1276. [CrossRef] [PubMed]

35. Johkan, M.H.; Shoji, K.; Goto, F.; Hahida, S.; Yoshihara, T. Blue light-emitting diode light irradiation of seedlings improves seedling quality and growth after transplanting in red leaf lettuce. HortScience 2010, 45, 1809-1814. [CrossRef]

36. van Ieperen, W.; Savvides, A.; Fanourakis, D. Red and blue light effects during growth on hydraulic and stomatal conductance in leaves of young cucumber plants. Acta Hortic. 2012, 956, 223-230. [CrossRef]

37. Farquhar, G.D.; Sharkey, T.D. Stomatal conductance and photosynthesis. Annu. Rev. Plant Physiol. 1982, 33, 317-345. [CrossRef]

38. Iino, M.; Ogawa, T.; Zeiger, E. Kinetic properties of the blue-light response of stomata. Proc. Natl. Acad. Sci. USA 1985, 82, 8019-8023. [CrossRef]

39. Lawson, T. Guard cell photosynthesis and stomatal function. New Phytol. 2009, 181, 13-34. [CrossRef]

40. Zeiger, E.; Talbott, L.D.; Frechilla, S.; Srivastava, A.; Zhu, J. The guard cell chloroplast: A perspective for the twenty-first century. New Phytol. 2002, 153, 415-424. [CrossRef]

41. Ohashi, K.K.; Matsuda, R.; Goto, E.; Fujiwara, K.; Kurata, K. Growth of rice plants under red light with or without supplemental blue light. Soil Sci. Plant Nutr. 2006, 52, 444-452. [CrossRef]

42. Matsuda, R.; Ohashi-Kaneko, K.; Fujiwara, K.; Goto, E.; Kurata, K. Photosynthetic characteristics of rice leaves grown under red light with or without supplemental blue light. Plant Cell Physiol. 2004, 45, 1870-1874. [CrossRef]

43. Zheng, L.; Van Labeke, M.C. Long-term effects of red- and blue-light emitting diodes on leaf anatomy and photosynthetic efficiency of three ornamental pot plants. Front. Plant Sci. 2017, 8, 917. [CrossRef] [PubMed]

44. Wang, J.; Lu, W.; Tong, Y.X.; Yang, Q.C. Leaf morphology, photosynthetic performance, chlorophyll fluorescence, stomatal development of lettuce (Lactuca sativa L.) exposed to different ratios of red light to blue light. Front. Plant Sci. 2016, 7, 250. [CrossRef] [PubMed] 
45. Hazarika, B.N. Morpho-physiological disorders in in vitro culture of plants. Sci. Hortic. 2006, 108, $105-120$. [CrossRef]

46. Su, N.N.; Wu, Q.; Shen, Z.G.; Xia, K.; Cui, J. Effects of light quality on the chloroplastic ultrastructure and photosynthetic characteristics of cucumber seedlings. Plant Growth Regul. 2014, 73, 227-235. [CrossRef]

47. Li, C.X.; Xu, Z.G.; Dong, R.Q.; Chang, S.X.; Wang, L.Z.; Khalil, U.R.M.; Tao, J.M. An RNA-Seq analysis of grape plantlets grown in vitro reveals different responses to blue, green, red LED Light, and white fluorescent light. Front. Plant Sci. 2017, 8, 78. [CrossRef]

48. Yamazaki, J.; Kamimura, Y. Relationship between photosystem stoichiometries and changes in active oxygen scavenging enzymes in natural grown rice seedlings. Plant Growth Regul. 2002, 36, 113-120. [CrossRef]

Publisher's Note: MDPI stays neutral with regard to jurisdictional claims in published maps and institutional affiliations.

(C) 2020 by the authors. Licensee MDPI, Basel, Switzerland. This article is an open access article distributed under the terms and conditions of the Creative Commons Attribution (CC BY) license (http://creativecommons.org/licenses/by/4.0/). 